\title{
Religion, reason, controversies and perspectives in clinical and research ethics
}

"This correspondence is now closed": but in medical ethics the traditional editorial fiat is often less easy to issue. The quality of argument and counter-argument demonstrated by so many contributors to the Journal of Medical Ethics illustrates not so much that they are undefeated because they have gone on trying, but the existential importance, for them and for many of their readers, of the complex questions they attempt to articulate and clarify. This is well illustrated in the current issue of the journal by papers which both contribute to existing ethical debates and open up new perspectives.

Among those contributing to existing ethical debates, three involve lively exchanges between different contributors. In a paper published first online in April 2014 and subsequently in the March 2015 issue, the Oxford theologian Nigel Biggar argued that "religion deserves a place in secular medicine": "secular medicine", he suggested, "should be understood... not as a space that is universally rational because it is religion-free, but as a forum for the negotiation of rival reasonings", including those of religion, always provided they avoid "appeals to religious authorities" and adopt "reasonable means of persuasion". ${ }^{1}$ Biggar's paper quickly attracted critical commentaries, albeit from widely different philosophical premises: three of these are published in this issue, together with Biggar's response. Two commentaries, by Kevin Smith (see page 867 ) and Xavier Symons (see page 870), take issue with Biggar from the standpoint of their respective author's interpretation of Utilitarianism (Smith) and Natural Law Theory (Symons). While it is clear to Smith "that the flawed empirical basis, lack of rationality and nonuniversality inherent in religion disqualify it from ethical discourse", it is equally clear to Symons "that "theistic natural law" gives us the resources to defend using reason alone ostensibly faith-based positions in healthcare ethics". A third commentary, by Brian Earp (see page 865) is more nuanced but no less critical: while arguing that "religion (as most people would understand the term) should not play a role in shaping secular health policy", he suggests that this (for example abortion policy being "shaped" by Roman Catholic doctrine) does not seem to be what Biggar is arguing for: rather, Earp suggests, "Biggar seems to be using the term 'religion' to refer obliquely to what most people would call 'moral philosophy'”, an 'inoffensive - but also unoriginal' interpretation.

Responding to these critics (see page 873), Biggar concedes to Symons that in his original paper he had used the word 'religion' too broadly and that what actually "deserves a place in secular medicine" is, more precisely, "a rationally developed ethics that is ultimately based on beliefs about religious realities", or a "theistic moral philosophy". These definitions, Biggar claims, have "the advantage of making clear that religious belief and philosophical method need not be alternatives". For this reason Biggar cedes no ground to what he characterizes as the "narrowly logical and empiricist concept of reason" which informs "Smith's sharp contrast between philosophy and religion”. By the same token, Biggar is happy to agree with Earp that "the moral theologian's modus operandi is 'not so very different' from that of any decent moral philosopher". The different premises, concepts and conclusions of the moral theologian and the atheist philosopher, however, may mean that what they understand by reason also is different. "A genuinely liberal public forum", Biggar concludes, "will recognize that, and not confuse a particular, substantively atheist position with reason itself".

What seems fairly clear from these arguments and counterarguments is that much depends on how the words 'religion' and 'reason' are understood; and, perhaps more controversially, that this in turn depends less on impartial reasoning than on intersubjective experience. If that is correct, and given the diversity of human experience, a final victory by either side in this particular 'culture war' seems highly unlikely. Or is that to take too short-term a view? The philosopher J L Schellenberg makes the intriguing suggestion that post-Enlightenment and especially post-Darwinian conflicts between "rational" and "religious" thinking may reflect, on both sides, a rather primitive stage in humanity's cultural evolution, and that if it is able to avoid destroying itself and perhaps the planet in the next few centuries, humanity may be "led from the thesis of traditional religious belief and the antithesis of Enlightenment thought to a new synthesis of ideas both religious and rational well fitted to stimulate and guide the next stages of human evolution". ${ }^{2}$ How far that Hegelian prospect merits serious consideration however is for readers and not this editorial to decide.

Contributions to less metaphysical and more ethical current debates or discussions are made in papers by Franklin G Miller (see page 885) and Udo Schuklenk and Suzanne van de Vathorst (see page 887) and by Rob Lawlor (see pages 893 and 899) and Tony Hope (see page 897). Miller writes that the claim that physician assisted death for patients with 'treatment-resistant' depression but lacking a terminal prognosis should become a legal option, overlooks "the important question" of "the professional integrity of physicians". Arguing that physician-assisted death is compatible with professional integrity only as a last resort, Miller concludes that prognostic uncertainty in these cases makes it incompatible. Schuklenk and van de Vathorst disagree on several grounds, including the argument that professional integrity should also be patient-centred and hence not violated if a doctor agrees to what he or she judges to be a competent patient's reasonable request for such assistance. The exchange between Lawlor and Hope is also in part about professional integrity: although it arises from the consideration of the philosophical non-identity problem, it soon moves to embrace the question of whether writers in applied ethics have a responsibility to present a "balanced overview" of different philosophical positions - an illuminating and well-mannered exchange leading eventually to a degree of nuanced agreement between the participants.

New perspectives on a variety of other current ethical and legal controversies are addressed in papers by Greg Moorlock 
(see page 875), Michelle Rydon-Grange (see page 880) and Johannes Kneiss (see page 889 ). Moorlock examines the question of what, beyond distaste with the idea of a 'beauty contest', might be wrong with non-directed altruistic living donation of human organs via dedicated websites: having carefully dissected the ethical and practical arguments for and against, he concludes that they are more evenly balanced, and the importance of altruism more questionable, than may seem at first sight. Initial reactions, in this case to catastrophic failures in modern healthcare settings, are also questioned by Rydon-Grange, who in a paper that is surely a must for health-care managers, demonstrates how "a psychological analysis of key factors, typically present in clinical contexts where serious failures of care occur" may be more helpful in learning what has gone wrong and how it might be put right than the imposition of new legal duties and sanctions. Considering sanctions of a different kind, in relation to patients and specifically to obesity, but what, Kneiss asks, of people whose "true interest is in pursuing an unhealthy lifestyle"? 'Hard paternalism' in their case is ethically unacceptable, but engaging in a softer version may be morally justified if it also nudges and enables what he calls "non-voluntary overeaters" towards a more healthy lifestyle.

New perspectives in Research Ethics are also addressed in this issue, in papers by Nicholas Greig Evans, Marc Lipsitch and Meira Levinson (see page 901), Kathryn Therese Mngadi, Janet Frohlich, Carl Montague, et al (see page 909), and Sophie L Niemansburg, Michelle G J L Habets, Wouter J A Dhert et al (see page 914). These examine ethical aspects of, respectively, biosafety in research resulting in the creation of potential pandemic pathogens, reimbursement of participants in trials combined with post-trial access, and selection of participants for preventive regenerative medicine trials who are at risk of developing disease related to degenerative abnormalities. Each of these papers demonstrates careful analysis and constructive proposals concerning these complex and continually developing areas of research ethics. A final paper in this issue, by Omosivie Maduka and Osaretin Odia, discusses clinical and public health aspects of the Ebola outbreak with particular reference to ethical challenges encountered and lessons learnt in Nigeria, but from which other countries also have much to learn.

\section{REFERENCES}

1 Biggar N. Why religion deserves a place in secular medicine. J Med Ethics 2015;41:229-33.

2 Schellenberg JL. Evolutionary Religion. Oxford: Oxford University Press 2013:158. 